\title{
Entrepreneurial Attitudes and Skills Internalization of
} Chinese Students'

Jumardi Budiman ${ }^{1}$

Universitas Tanjungpura, Indonesia

\section{Article Info}

Article history:

Received: 27 December 2019;

Accepted: 20 February 2020;

Published: 1 March 2020.

\begin{abstract}
This study attempts to know about the process of internalization attitudes and skill of entrepreneurship to their students chinese. Object this study were chosen based on stereotype and its phenomena developing in the community west Kalimantan that of the Chinese must be traders. Methods used are qualitative to technique data collection using interviews and observation. Respondents this research is the student will Emmanuel Pontianak of Chinese ethnic and came from families entrepreneurs. Data analysis techniques used that is the reduction, data presentation of data and the withdrawal of conclusion. The result showed that the process internalization attitudes and entrepreneurship skills students derived from the informal education of the community, community school, and their peers. The business management internalization attitudes and skills to their students covering thriftiness, productive and orientation independent, able to make decisions and, bear the consequences not easily discouraged, and finish the first new demanding the right
\end{abstract}

Keywords:

Entrepreneurial Attitude; Skills Internalization; Chinese Student.

\begin{abstract}
Abstrak
Penelitian ini bertujuan untuk mengetahui proses internalisasi sikap dan keterampilan berwirausaha pada siswa Tionghoa. Objek penelitian ini dipilih berdasarkan streteotip dan fenomena yang berkembang di masyarakat Kalimantan Barat bahwa orang Tionghoa pasti menjadi pedagang. Metode yang digunakan adalah kualitatif dengan teknik pengumpulan data menggunakan wawancara dan observasi. Responden penelitian ini adalah siswa SMK Imanuel Pontianak keturunan Tionghoa dan berasal dari keluarga pengusaha. Teknik analisa data yang digunakan yakni reduksi data, penyajian data dan penarikan kesimpulan. Hasil penelitian menunjukkan bahwa proses internalisasi sikap dan keterampilan berwirausaha pada siswa berasal dari pendidikan informal yakni keluarga, lingkungan masyarakat, sekolah komunitas, dan teman sebaya. Bentuk internalisasi sikap dan keterampilan mengelola usaha pada siswa meliputi sikap hemat dan orientasi produktif, mandiri, mampu membuat keputusan dan menanggung konsekuensinya, tidak mudah putus asa, dan menyelesaikan kewajiban terlebih dahulu baru menuntut hak.
\end{abstract}

\section{How to Cite:}

Budiman, Jumardi. (2020). Entrepreneurial Attitudes and Skills Internalization of Chinese Students'. Jurnal Pendidikan Ekonomi \& Bisnis, 8 (1), 43-53. https://doi.org/10.21009/JPEB.008.1.5 


\section{INTRODUCTION}

Pontianak, Kalimantan Barat is one of the big cities in Indonesia in which the Chinese population has a great number. Indonesia census in 2010 showed the majority ethnic in Indonesia is Javanese (40.22\%) while Chinese is the minority which stands in the 18th rank with the population was counted as 2.832 .510 , though based on another survey conducted by abroad-organization, the Chinese population in Indonesia was around 11 million(Christian, 2017). However, there is no official data issued elated to the number of Chinese populations in Pontianak. The Chinese ethnicity is living in groups and spreading in the district of Pontianak Selatan, Tenggara, and Utara.

The absence of official data issued related to the Chinese population is a problem that must be settled seriously by any stakeholder as they have been living from generation to generation for a hundred years in Pontianak(Christian, 2017). The dynamic and identity crisis of Chinese ethnic in Indonesia is closely related to the political policies atmosphere of the sovereigns, where they have particular goals to locate the Chinese suited to their political purposes (Christina \& Maftuh, 2016).

Some literature explained the history of the arrival of Chinese to Kalimantan Barat was started from the 7th century through trade cooperation with Sambas and Mempawah kingdom, but they came and stayed indeed as the laborers in the 17th centuries. This is also the starting point for the Chinese trade association in Kalimantan Barat and built Chinese villages that assimilated with the local villages (Matanasi, 2016).

As the assimilation process that lasts for decades could not change and abandon their originality trait as the offspring of Chinese in Indonesia. Even, the assimilation that occurred in many regions made its cultures grow differently in each province. This diversity of cultural identity is caused by some factors such as dialect, region, and clan names (Christian, 2017). Besides, the changing of cultures identity of Indonesia Chinese is as the political effect (sovereign), and western cultures or other Asian cultures exposures.

The characteristic of Chinese in Pontianak can be seen from the use of the Khek dialect in their daily communication. It is different compared to the Chinese in Surabaya or Semarang who can speak Javanese fluently, it is caused by the strict political policies in the new order era so that the Chinese who are staying in Java do not accustom with their mother tongue (Hudayah \& Winarni, 2014).

Some historical and cultural research above clearly explained the arrival of Chinese in Indonesia is as the effect of trade relationship to the kingdoms in this archipelago, included in Kalimantan Barat. Their job as the trader is now inherited by the Chinese who are Indonesian. This condition becomes a "legitimacy" for the Chinese people that being the traders or businessmen are kinds of jobs that must be committed with the 3C principles Cengli, Cincai and Coan (Pudhi Devanti, 2013). Besides the historical factors, most of Chinese that are traders or businessmen is a part of the prereform political system that did not give them chances and spaces to be a civil servant or bureaucrat (Lee \& Chan, 1998).

Being the traders is the stereotype of the economy of Chinese people in Indonesia. For the non-Chinese in Indonesia, especially in Pontianak where most of the population is Malay and Arabic descendant, call these Chinese mid-to-high class businessmen as "Tauke or Toke" that means boss or the one who own a company and many other. These "Tauke" tend to have multi-big businesses that can support the local own-source revenue. As for the mid-to-low group, generally, they work for other Chinese traders or be the small-scale traders (Shi \& Dana, 2013; Zapalska \& Edwards, 2001).

However, a positive value of this stereotype for the Chinese people is the work hard principle. The phenomenon that occurred in public shows that Chinese tend to work (earn money by themselves) rather than asking from others, or in other words, it is better for them to be seconds traders and earn Rp.100 rather than earn Rp.1000 as the beggars. The second positive value of stereotype is Sengke' (stingy) which is more 
appropriate to say that the Chinese are capable of managing and saving money. When they have Rp.100, so they will save Rp.25 and the rest will be used as the venture capital (Wardayati, 2017).

These positive values in managing a business are inherited to the next generation in Chinese families. They always involve their children to work in their stores or shops as cashier or shop assistance and give the chances to their children to do a simple job or even harder (Kaijun \& Ichwatus Sholihah, 2015; Liu, Walley, Pugh, \& Adkins, 2020). That is the moment when the entrepreneurship values are inherited from the parents. Involving the children at the young ages is the best way to create them to be great businessmen in the future (Giacomin et al., 2011; Lili, 2011; Peng, Lu, \& Kang, 2012). This is one of the factors to create a business mentality from the children. Based on the study of Amin et.al. about career orientation of Chinese students showed that most Chinese students had a high career orientation since they were young as they had been taught and insisted to be able to help the family business (Amin, Wibowo, \& Nusantoro, 2014).

The explanation above elaborates that Chinese people have the business orientation as the result of experiences, political systems, and social interaction processes among them or with other societies (Fayolle \& Gailly, 2015). This research was conducted under this condition and made the researchers' team perceived it was needed and crucial to identify several factors and analyze the entrepreneurship attitudes and skills internalization process in Chinese people.

Entrepreneurship is the process of creating something which has different in value with attempts and times needed, financial, psychological, and social risks as well and also earns financial and personal satisfaction (Winarno, 2011). According to Grave, the characteristics of entrepreneur are "10 D", as follows: a) Dream; b) Decisiveness; c) Doers; d) Determination; e) Dedication; f) Devotion; g) Details; h) Destiny; i) Dollars; j) Distribute (Basrowi, 2012).

Internalization is an input process of a concept to ones to make the concept internalized to themselves. It will be faster with the involvement of the role-models (Rina, 2019; Vahlne \& Johanson, 2013). They have a person that is to be honored and be model for them so they can accept a set of norms that is performed through a model. This process is commonly called as identification in psychology or social. These attitudes and behaviors are manifested through learning or subconscious and conscious assimilation (Rais, 2012).

The State of the art of this research is compared to others with a similar theme are as follows: A research conducted by Rina was founding showed that the internalization of entrepreneurial competence and character had been applied through leadership activities so as to form the character and leadership skills of students. This study has implications for the school's efforts to give full attention for students to play a role in leadership activities and to provide support through a curriculum that supports the internalization of entrepreneurial competence and character (Rina, 2019).

The research conducted by Nurhamidah about internalizing the entrepreneurship education values in the curriculum in SMK Salafiyah Syafi'iyah Randangan, Gorontalo. The findings showed the internalization values of entrepreneurship had been applied in the teaching and learning process as it was inserted in the syllabus and lesson plan. The factors that supported this Internalization were the higher of students' learning motivation, the comfort classroom, the appropriate learning model, well-equipped with media, and the teacher acted as models well. Meanwhile, the factors that limit the internalization were the lateness of students who came to the class, the teacher's educational background did not suite, dan the varieties of comprehension levels, and a minimum of facilities provided at school (Nurhamidah, 2018). The strength of the research was it could identify the supporting and distracting factors of internalizing entrepreneurship values in the learning process, but the weakness of the research was it did not describe the research concept 
holistically as figured in the frame of concept.

The differences between this research and the current research conducted by the researcher were formal and informal education as covered in the research (Nurhamidah, 2018). The research conducted by Nastiti, Indarti and Rostiani about interest and the innovative ideas Indonesian and Chinese students conclude that there are differences of factors affect am innovative ideas between Indonesian and Chinese students. Innovative ideas interest a student of Chinese influenced by the need for the achievement of the locus of control, personal efficacy, and readiness instrument, while the Indonesian students by personal efficacy.

Excess this study has been able to identify various innovative ideas of factors affect the interest on students and compare by difference factor in the form of interestbased on ethnic origin countries and. As for weakness who writers have found on this research namely stratification of respondents did not equivalent between Indonesian students who are continuing their multiethnic and Taiwan who it is monoethnic.

The difference of this research about anything that is the day of the respondents who writers present, a method of, data available for analysis and research objectives technique (Nastiti, Indarti, \& Rostiani, 2010). Research by Herlina, et.al was founding "Market Day School" is one way to internalize entrepreneurial values that aims to help students have attitudes, knowledge, and skills to act in line with entrepreneurial values. In this program hone students' ability to be independent, creative, risk-taking, action-oriented, leadership, and hard work (Herlina et al., 2019). Research by Sanchez was founding The findings contribute to the theories of planned behavior, and to the literature of EE itself, by revealing the effect of specific benefits for the students derived from the EE program (Sánchez, 2013).

Based on the previous research, the novelty of this research covers a broad discussion that was to identify the students' internalization process based on formal and informal education. Besides, the subjects of this research particularly were the Chinese students. It was in line with the purpose of this research to identify and describe the entrepreneurship attitudes and skills internalization process of Chinese students.

\section{METHOD}

\section{Research approach}

The approach used in this research was qualitative research since the researchers intended to reveal comprehensively the entrepreneurship attitudes and skills internalization process of the Chinese students in SMK Immanuel. Qualitative approach was chosen as the following reasons: (1) the existing reality basically was multiple, constructed, and holistic; (2) interactive relationship between the sources of information and cannot be separated;(3) time and context only that might relate to the working hypothesis; (4) all entities are simultaneous that might not distinguish causeeffect; (5) the research is free of value. It was descriptive as the research finding was elaborated based on the verbal facts (interviews) to simplify the revealing of research findings. It was inductive as the researchers did not intend to test the existing theories but to abstract toward the facts compiled related to aspects or phenomena researched (Basri, 2011).

\section{Research Variable}

The research variable was the entrepreneurship attitudes and skills internalization process that covered the aspects of the entrepreneurship attitudes and skills internalization process; and other aspects that support the internalization process. 


\section{Source of data}

The source of data used as the research subjects and informants were the Chinese students in SMK Immanuel that came from the businessmen families. Besides, the researchers also used other documents as the supporting source of data.

\section{Data collecting technique}

To get valid data, an appropriate technique of data collection is needed. The technique used in this research were interview, observation and documentary study.

\section{Data analysis technique}

As stated previously, the data analysis technique used in this research was a qualitative approach in which comprised data reduction, data display, and conclusion drawing /verification. In the data reduction phase, the researchers selected, simplified, abstracted, and transformed the rough data that was collected through interviews and family and social observation.

In the data display, the researchers developed a structured description of the information to draw a conclusion and take the action. The data display that is commonly used is in a narrative form. In the conclusion drawing and verification phase, the researchers tried to seek the meaning of any phenomenon collected from the field, noticed the regularity and configuration that might exist, and the causality line of the entrepreneurship attitudes and skills internalization aspects of Chinese students in SMK Immanuel

\section{RESULTS AND DISCUSSION}

Based on the previous theoretical review, that internalization defined as the process of instilling values to someone's life so that the values can be reflected by the attitudes and behavior acted in daily life. The entrepreneurship attitudes and skills internalization is intended as the process of instilling the entrepreneurship values to the students so that it can be seen by how they behave daily.

The students' entrepreneurship attitudes and skills internalization started from the family side. The stereotype that embedded to the Chinese that they are businessmen is not something wrong. Even though there are numbers of Chinese people are labors (employers or staffs), generally, they worked for other Chinese as the starting point or their first step to learn how to manage an enterprise and earn money for the capital simultaneously in which they can also build their enterprise at the end.

Based on the review of the historical notice, the stereotype that Chinese are businessmen was related to the policies issued by the new order government for 32 years. At that time, the Chinese people were perceived as non-indigenous and to be worried about the spreading of communism so they were not recognized as Indonesia citizenship. Chinese people were not allowed to have an ID card so they lost their rights as Indonesian citizens. They could not apply for any job in the companies and to be civil servants, police, and soldier, so that the only thing they could do was trading. It became the main background that all Chinese were traders or businessmen at that time.

Every child that was born and raised around the business environment will have a mindset that tends to be independent and creative. The mindset formed by the daily interaction occurred to all family members especially father and mother. The tendencies to think and be independent have been taught by the parents to their children by giving them responsibilities to finish all the chores while the parents manage their business. The instilling of the independent attitudes was accompanied by the attitudes of not to be inferior and shame on the condition, otherwise, the parents accustomed their children to start over something with what they already have without 
asking and waiting for aid from others.

The very simple illustration of being independent that instilled is the "transactional" process done by the parents whenever their children ask for something or money to them. If the children ask for a bicycle from their parents, they need to fulfill the prerequisites given by the parents first and then they will get the bicycle. It is done by mostly Chinese parents, even financially they can afford it instantly but they want to teach their children not to be spoil and have more fun and also respect all the things that they get by working hard (Nastiti et al., 2010; Su \& Carney, 2013; Yang, 2013).

The interview showed that the fathers tended to be ignorant and decisive. It is done to instill an independent attitude toward the children so that they can survive in any situation. This kind of education pattern was based on the experiences of the parents that were poor and started all their business from zero so they want their offspring to be hard workers.

Internalizing entrepreneurship skills to the Chinese students is also started around their family. Based on the interview and observation conducted, it could be known that the Chinese students helped their parents in managing the business after school or extra class activities. There were also students asked to do door-to-door sales. Besides to improve their skills in managing a business, it is also an attempt to reduce their laziness and disgrace. The important philosophy is it would be better to earn money yourself than asking from others.

Based on the researchers' experiences and the research findings, the phenomena found that Chinese students have good competence in Mathematics and English. For the parents, these two subjects are very crucial to be mastered by their children as the primary skills they need in managing the business. Mathematic is basic in the calculation so it is expected that their children can calculate fast and accurately. Being good in English is expected to make their children can communicate fluently with other strangers and as the preparation whenever their business can be expanded globally.

Generally, the Chinese people in Pontianak reside in a group with their community. This situation is also related to the unpleasant historical experienced by them in the new order regime. The government did not admit their existence and basic rights in any policy issued, one of them is as stated in (SBKRI). SBKRI was perceived as the way of the government to distinguish the indigenous and the descendant of Chinese and India.

Besides, Chinese was frequently targeted in any inter-ethnic violence in the past that occurred in several areas in Indonesia. It was one of the reasons why they live in a group so they can protect each other. If there were some Chinese who went to other regions so they tend to seek a Chinese residence and built a house there as well.

In Pontianak, their residences are located on Gajahmada street, Tanjung Pura street, Sungai Raya Dalam street and sub-district Pontianak Timur (Siantan). In subdistrict Sungai Raya Kubu Raya, they reside in Parit Baru market.

This residential pattern affects the interaction among the Chinese people and also their children. This kind of social circumstance will extremely support the entrepreneurship attitudes internalization process of Chinese students because the people around them can be the models in behaving as the businessmen. Social circumstances can also give extra knowledge about entrepreneurship after they get basic knowledge at home.

Based on the interview and observation result, it showed that their interest to be a businessman was influenced by the circumstance around them (people and peers). Social circumstances also provided various knowledge to the students about the types of potential business, managing the business in the small, middle and big levels. This reality is perceived as crucial to the parents who want their children to be the successors of the business that has been established.

Social interaction with the environmental community also creates a unique design for students Chinese the next time they become entrepreneurs. This pattern of 
doing business is the major key to the success of Chinese entrepreneurs in business competition and the company other. This condition following the characteristic of research Handaru about entrepreneur through multiple discriminant analysis that concludes that there are differences between the business community entrepreneur of Chinese, Java, and Minang (Handaru, Pagita, \& Parimita, 2015).

The students' entrepreneurship attitudes and skills internalization are also influenced by the school environment. In Pontianak and Kubu Raya, there are some "Chinese community" schools. This term refers to the number of students in the school dominated by Chinese students. The schools are Santo Petrus Schooling, Imanuel Schooling, Gembala Baik Schooling, and Tunas Bangsa School. The result of the interview showed that the community in those schools were not intended to be created based on the similarity of ethnic, but more on the quality of the schools. For Chinese, the high school fees that were paid for the private school were perceived worthy to the quality offered by the school so the parents will do much effort to make their children study in the best schools. These similar purposes made them enrolled their children in those schools so it made a same-ethnic community. This is following research by Zhou, et.al; Raposo and Morris, et.al (Morris, Webb, Fu, \& Singhal, 2013; Raposo \& do Paço, 2011; Zhou \& Xu, 2012).

The homogeneous school environment made the entrepreneurship attitudes and skills internalization process get easier. It is caused by the student psychological factors which they are already teenagers, tend to be easily influenced by their peers rather than the older. The examples that are showed by their peers who are involved in helping their parents will be easy to be followed by the students.

Besides, if there are students who earn money and buy a thing themselves, it will be a prestige among their schoolmates because they are perceived as independent. This condition to be the cause of different perceptions of Chinese students orientation future careers with students of other ethnicities. This phenomenon following the test which has been done by Amin; Graevenitz (Amin et al., 2014; von Graevenitz, Harhoff, \& Weber, 2010).

The internalization process through the academic side was perceived as less effective in forming the students' entrepreneurship attitudes and skills. Entrepreneurship subject at school was less effective to form students' entrepreneurship mentality since it was more theoretical than practical. This statement support to result the research by Oosterbeek; Wang; Rauch (Oosterbeek, van Praag, \& Ijsselstein, 2010; Rauch \& Hulsink, 2015; Wang, Lu, \& Millington, 2011).

\section{Aspects that Support Internalization Process}

Based on the research findings, some aspects that support students' entrepreneurship attitudes and skills internalization process in SMK Immanuel such as family, social and formal educational environments. Those all aspects were integrated so the internalization process can be comprehensive. The internalization process to the students can be illustrated as follow: 


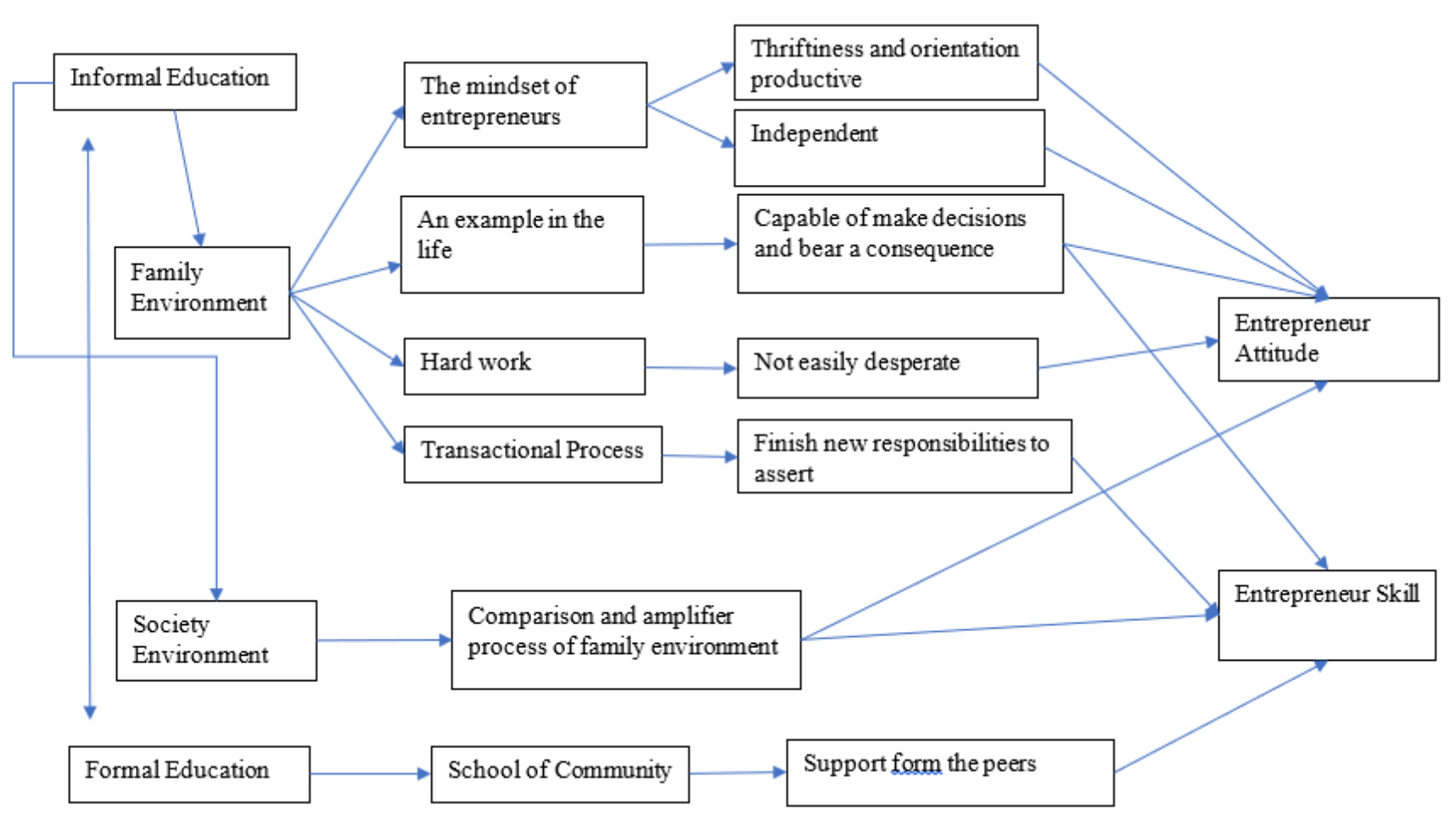

Figure 1. Entrepreneurship Attitudes and Skills Internalization Process

The process of the internalization of the family environment, a social environment and the environment of formal education in line with some studies surveyed by an author with of the main differences in perspective and the scope of a study jointly conducted. A picture above shows that a groove to their students the internalization of the explained that the Chinese and relatedness of formal education and informal in forming the attitudes and skill to their students explained that the Chinese have been decided like an entrepreneur. A writer deliberately distinguishes between the attitude by the aspect of skill to give the boundary between both women and men have. According to author the measures and the behavior is more directed to the action of in response towards the information received by students, while the skills of more lead to a durable the ability of an individual in resolving duty on a skillful architect and master builder and private physician practices percent even though what happened in a groove above there is the act of one who become the framer of both women and men have.

\section{CONCLUSIONS AND SUGGESTIONS}

Based on the research findings described in the previous section, it can be concluded that: 1) the entrepreneurship attitudes and skills of Chinese students in SMK Imanuel are the internalization process that occurred gradually and sustainably; 2) entrepreneurship attitudes and skills internalization process of Chinese students occurred continuously in family, social and school environments; 3) the aspects that support entrepreneurship attitudes and skills internalization process of Chinese students are informal education at home and neighborhood and formal education at community school.

The researchers suggested that: 1) the parents should consistently educate the students to be entrepreneurs and create a situation that can support the process; 2 ) the schools' parties should be able to complete the entrepreneurship learning materials that are interest-improvement and managing-skills oriented. 


\section{REFERENCES}

Amin, Z. N., Wibowo, M. E., \& Nusantoro, E. (2014). Perbandingan Orientasi Karir Siswa Keturunan Jawa dengan Siswa Keturunan Tionghoa. Indonesian Journal of Guidance and Counseling, 3(3), 8-16. $\quad$ Retrieved from https://journal.unnes.ac.id/sju/index.php/jbk/article/view/3778

Basri, M. (2011). Internalization of Attitudes and Intention in the Morality of Students of Economics Faculty of Economics Education Program State University of Malang (Malang University). Retrieved from http://karya-ilmiah.um.ac.id/index.php/disertasi/article/view/14002

Basrowi. (2012). Kewirausahaan Untuk Perguruan Tinggi. Ghalia Indonesia.

Christian, S. A. (2017). Identitas Budaya Orang Tionghoa Indonesia. Jurnal Cakrawala Mandarin, 1(1), 11. https://doi.org/10.36279/apsmi.v1i1.11

Christina, B. W., \& Maftuh. (2016). TRANSFORMASI NILAI-NILAI BUDAYA MASYARAKAT ETNIS TIONGHOA SEBAGAI SUMBER PEMBELAJARAN IPS (Studi Kasus di Desa Sewan Kota Tangerang). Jurnal Pendidikan Ilmu Sosial, 25(1), 41-57. Retrieved from https://www.google.com/search?q=pemuda+sebagai+generasi+penerus+bangsa+journal\&rlz=1 C1CHBD_idID836ID836\&oq=pemuda+sebagai+generasi+penerus+bangsa+journal\&aqs=chro me..69i57.21173j0j7\&sourceid=chrome\&ie=UTF-8

Fayolle, A., \& Gailly, B. (2015). The Impact of Entrepreneurship Education on Entrepreneurial Attitudes and Intention: Hysteresis and Persistence. Journal of Small Business Management, 53(1), 75-93. https://doi.org/10.1111/jsbm.12065

Giacomin, O., Janssen, F., Pruett, M., Shinnar, R. S., Llopis, F., \& Toney, B. (2011). Entrepreneurial intentions, motivations and barriers: Differences among American, Asian and European students. International Entrepreneurship and Management Journal, 7(2), 219-238. https://doi.org/10.1007/s11365-010-0155-y

Handaru, A. W., Pagita, M. P., \& Parimita, W. (2015). KARAKTERISTIK ENTREPRENEUR MELALUI MULTIPLE DISKRIMINAN ANALISIS (Studi Pada Etnis Tionghoa, Jawa dan Minang di Bekasi Utara). JRMSI - Jurnal Riset Manajemen Sains Indonesia, 6(1), 351. https://doi.org/10.21009/jrmsi.006.1.02

Herlina, M., A. Ghani, A., Sa'ud, U., Disman, D., Sopandi, W., \& Murwantono, D. (2019). An Internalization of Entrepreneurship's Values Through Market Day in Elementary School. Proceedings of the Proceedings of the 2nd International Conference on Local Wisdom, INCOLWIS 2019, August 29-30, 2019, Padang, West Sumatera, Indonesia. https://doi.org/10.4108/eai.29-8-2019.2289136

Hudayah, N., \& Winarni, R. (2014). Pengaruh Kebijakan Pemerintah Indonesia Terhadap Kehidupan Etnis Tionghoa Di Bidang Politik, Sosial Budaya,Dan Ekonomi Di Kabupaten Jember Dari Zaman Orde Lama Sampai Zaman Reformasi Pada Tahun 1998-2012. Publika Budaya, 2(2), 19-31. Retrieved from https://jurnal.unej.ac.id/index.php/PB/article/view/1506

Kaijun, Y., \& Ichwatus Sholihah, P. (2015). A comparative study of the Indonesia and Chinese educative systems concerning the dominant incentives to entrepreneurial spirit (desire for a new venturing) of business school students. Journal of Innovation and Entrepreneurship, 4(1), 1. https://doi.org/10.1186/s13731-014-0014-0

Lee, J., \& Chan, J. (1998). Chinese entrepreneurship: A study in Singapore. Journal of Management Development, 17(2), 131-141. https://doi.org/10.1108/02621719810206041

Lili, Z. (2011). Comparative study of China and USA's colleges entrepreneurship education from an international perspective. Journal of Chinese Entrepreneurship, 3(3), 185-194. https://doi.org/10.1108/17561391111166966

Liu, T., Walley, K., Pugh, G., \& Adkins, P. (2020). Entrepreneurship education in China. Journal of Entrepreneurship in Emerging Economies, ahead-of-p(ahead-of-print).

https://doi.org/10.1108/JEEE-01-2019-0006 
Matanasi, P. (2016). Orang-orang Tionghoa di Singkawang. Retrieved from https://tirto.id/orangorang-tionghoa-di-singkawang-b4Y8

Morris, M. H., Webb, J. W., Fu, J., \& Singhal, S. (2013). A Competency-Based Perspective on Entrepreneurship Education: Conceptual and Empirical Insights. Journal of Small Business Management, 51(3), 352-369. https://doi.org/10.1111/jsbm.12023

Nastiti, T., Indarti, N., \& Rostiani, R. (2010). Minat Berwirausaha Mahasiswa Indonesia Dan Cina. Journal of Management and Business, 9(2), 188-189. https://doi.org/10.24123/jmb.v9i2.164

Nurhamidah, N. (2018). Internalisasi Nilai-Nilai Pendidikan Kewirausahaan dalam Kurikulum di SMK Salafiyah Syafiiyah. Jurnal Ilmiah AL-Jauhari: Jurnal Studi Islam Dan Interdisipliner, 3(1), 17-32. https://doi.org/10.30603/jiaj.v3i1.683

Oosterbeek, H., van Praag, M., \& Ijsselstein, A. (2010). The impact of entrepreneurship education on entrepreneurship skills and motivation. European Economic Review, 54(3), 442-454. https://doi.org/10.1016/j.euroecorev.2009.08.002

Peng, Z., Lu, G., \& Kang, H. (2012). Entrepreneurial Intentions and Its Influencing Factors: A Survey of the University Students in Xi'an China. Creative Education, 03(08), 95-100. https://doi.org/10.4236/ce.2012.38B021

Pudhi Devanti, A. (2013). UKM Indonesia vs Pedagang Tionghoa di Indonesia. Jurnal Akuntansi AKUNESA, 1(2). Retrieved from https://jurnalmahasiswa.unesa.ac.id/index.php/jurnalakuntansi/article/view/719/503

Rais, M. (2012). Internalisasi Nilai Integrasi Untuk Menciptakan Keharmonisan Hubungan Antar Etnik. Retrieved from http://repository.upi.edu/id/eprint/7652

Raposo, M., \& do Paço, A. (2011). Entrepreneurship education Relationship between education and entrepreneurial activity. Psicothema, 23(3), 453-457.

Rauch, A., \& Hulsink, W. (2015). Putting Entrepreneurship Education Where the Intention to Act Lies: An Investigation Into the Impact of Entrepreneurship Education on Entrepreneurial Behavior. Academy of Management Learning \& Education, 14(2), 187-204. https://doi.org/10.5465/amle.2012.0293

Rina, L. (2019). STUDENT LEADERSHIP IN SCHOOL: INTERNALIZATION OF ENTREPRENEURIAL COMPETENCE AND CHARACTER. Jurnal Manajemen Dan Kewirausahaan, 21(1), 1-8. https://doi.org/10.9744/jmk.21.1.1-8

Sánchez, J. C. (2013). The Impact of an Entrepreneurship Education Program on Entrepreneurial Competencies and Intention. Journal of Small Business Management, 51(3), 447-465. https://doi.org/10.1111/jsbm.12025

Shi, H. X., \& Dana, L. P. (2013). Market orientation and entrepreneurship in Chinese family business: A socialisation view. International Journal of Entrepreneurship and Small Business, 20(1), 1-16. https://doi.org/10.1504/IJESB.2013.055690

Su, E., \& Carney, M. (2013). Can China's family firms create intellectual capital? Asia Pacific Journal of Management, 30(3), 657-675. https://doi.org/10.1007/s10490-012-9302-z

Vahlne, J.-E., \& Johanson, J. (2013). The Uppsala model on evolution of the multinational business enterprise - from internalization to coordination of networks. International Marketing Review, 30(3), 189-210. https://doi.org/10.1108/02651331311321963

von Graevenitz, G., Harhoff, D., \& Weber, R. (2010). The effects of entrepreneurship education. Journal of Economic Behavior \& Organization, 76(1), 90-112. https://doi.org/10.1016/j.jebo.2010.02.015

Wang, W., Lu, W., \& Millington, J. K. (2011). Determinants of Entrepreneurship Intention among College Students in China and USA. Journal of Global Entrepreneurship Research, 1(1), 3544.

Wardayati, S. (2017). PENGARUH LATAR BELAKANG ETNIS, KECERDASAN ADVERSITAS DAN REGULASI DIRI DALAM BELAJAR TERHADAP ORIENTASI WIRAUSAHA SISWA SMP NEGERI 31 SURABAYA. Jurnal Ekonomi Pendidikan Dan Kewirausahaan, 5(2), 199218. https://doi.org/10.1017/CBO9781107415324.004 
Winarno. (2011). Pengembangan Sikap Entrepreneurship dan Intrapreneurship. Jakarta: Indeks. Yang, J. (2013). The Theory of Planned Behavior and Prediction of Entrepreneurial Intention Among Chinese Undergraduates. Social Behavior and Personality: An International Journal, 41(3), 367-376. https://doi.org/10.2224/sbp.2013.41.3.367

Zapalska, A. M., \& Edwards, W. (2001). Chiness Entreprenurship in a Cultural and Economic Perspective. Journal of Small Busines Management, 39(3), 286-292.

Zhou, M., \& Xu, H. (2012). A Review of Entrepreneurship Education for College Students in China. Administrative Sciences, 2(1), 82-98. https://doi.org/10.3390/admsci2010082 